\section{UCT4B, A NEW ANTITUMOR ANTIBIOTIC WITH TOPOISOMERASE II MEDIATED DNA CLEAVAGE ACTIVITY, FROM Streptomyces sp.}

\author{
Sho-ZOU KaWAda ${ }^{\dagger}$, Yoshinori Yamashita, \\ Youichi Uosaki, Katsushige GoMI ${ }^{\dagger \dagger}$, \\ TOSHIAKI IWASAKI $^{\dagger \dagger}$, TOSHIMITSU TAKIGUCHI ${ }^{\dagger \dagger}$ \\ and Hirofumi NaKano \\ Kyowa Hakko Kogyo Co., Ltd, \\ †Technical Research Laboratories, \\ Kyowa-machi, Houfu, Yamaguchi, \\ ${ }^{\dagger}$ Pharmaceutical Research Laboratories, \\ Nagaizumi-cho, Shizuoka, \\ and Tokyo Research Laboratories, \\ 3-6-6 Asahimachi, Machida, Tokyo, Japan
}

(Received for publication March 17, 1992)

DNA topoisomerases are enzymes that alter DNA conformation through a concerted breaking and rejoining of DNA strands thereby controlling the topological state of $\mathrm{DNA}^{1)}$. Topoisomerase II has been shown to be the primary cellular target for a number of clinically important antitumor agents with diverse and unrelated chemical structures ${ }^{2,3}$. These antitumor drugs, referred as to "topoisomerase II poisons", trap the enzyme in an intermediary reversible complex with DNA, termed "cleavable complex" which prevents the final rejoining step of the reaction and results in increased DNA strands breaks ${ }^{2,3)}$. It is believed that the ability to form the cleavable complex with topoisomerase II is responsible for antitumor activity of these drugs.

In order to identify a specific new topoisomerase II poison, we have screened cultures of actinomycetes and fungi for their ability to induce topoisomerase II mediated DNA cleavage in vitro. We found that the diterpeniod antitumor antibiotics terpentecin and clerocidin are potent inducers of DNA cleavage ${ }^{4)}$, and have now isolated a novel compound with DNA cleavage activity, UCT4B, from the culture broth of actinomycetes which produces terpentecin.

The producing organism was isolated from a soil collected in Yamaguchi Prefecture, Japan and was assigned to the genus Streptomyces. Fermentation was carried out at $28^{\circ} \mathrm{C}$ for 3 days under aeration of 400 liters/minute and agitation at $100 \mathrm{rpm}$ in 200-liter tank fermenter containing 100 liters of culture medium consisting of sucrose $5 \%, \mathrm{KNO}_{3}$ $3 \%, \quad \mathrm{KH}_{2} \mathrm{PO}_{4} \quad 0.05 \%, \quad \mathrm{MgSO}_{4} \cdot 7 \mathrm{H}_{2} \mathrm{O} \quad 0.05 \%$, $\mathrm{Mg}_{3}\left(\mathrm{PO}_{4}\right)_{2} \cdot 8 \mathrm{H}_{2} \mathrm{O} 0.05 \%, \mathrm{pH} 7.0$. UCT4B accumulated in the culture medium. The culture filtrate was applied to a column of Diaion HP-20 (Mitsubishi Chemical Industries Limited). The column was washed with deionized water-MeOH $(1: 1)$ and eluted with deionized water-MeOH (3:7). The active eluate was concentrated and applied to a column of Diaion HP-20SS. The column was washed with deionized water-MeOH $(1: 1)$ and the UCT4B containing fraction was eluted with deionized water- $\mathrm{MeOH}(3: 7)$. The eluate was concentrated and extracted with ethyl acetate at $\mathrm{pH}$ 4.0. The active

Table 1. Physico-chemical properties of UCT4B.

\begin{tabular}{ll}
\hline $\begin{array}{l}\text { Appearance } \\
\text { Molecular formula }\end{array}$ & White powder \\
$\begin{array}{l}\text { HREI-MS }(m / z): \\
\mathrm{C}_{20} \mathrm{H}_{28} \mathrm{O}_{7}\end{array}$ \\
$\quad \begin{array}{l}\text { Obsd } \\
\text { Calcd for } \mathrm{C}_{20} \mathrm{H}_{28} \mathrm{O}_{7}\end{array}$ & $380.1818\left(\mathrm{M}^{+}\right)$ \\
$\mathrm{UV} \lambda_{\max }$ & End absorption \\
IR (KBr) $v \mathrm{~cm}^{-1}$ & $3431,2966,1707,1385,1016$, \\
& 999 \\
Solubility: & \\
$\quad$ Soluble & $\mathrm{MeOH}, \mathrm{CHCl}_{3}$, EtOAc \\
$\quad$ Slightly soluble & $\mathrm{H}_{2} \mathrm{O}, \mathrm{CH}_{3} \mathrm{CN}$ \\
$\quad$ Insoluble & $n-\mathrm{Hexane}$ \\
Stability & Stable at pH $2 \sim 8$ \\
\hline
\end{tabular}

Fig. 1. Structure of UCT4B, terpentecin and clerocidin.<smiles>CC1C(O)C(=O)C2(C)C(CO)=CCCC2C1(CC(O)C1(C(=O)C=O)CO1)CC(F)(F)Cl</smiles>

UCT4B<smiles>CC1=CCCC2C1(C)C(=O)C(O)C(C)C2(C)CC(O)C1(C(=O)C=O)CO1</smiles>

Terpentecin<smiles>CC1CCC2(C)C(C=O)=CCCC2C1(C)CC(O)C1(C(=O)C=O)CO1</smiles>

Clerocidin 
Fig. 2. Topoisomerase II dependent DNA cleavage activity of UCT4B, terpentecin, clerocidin and VP-16.

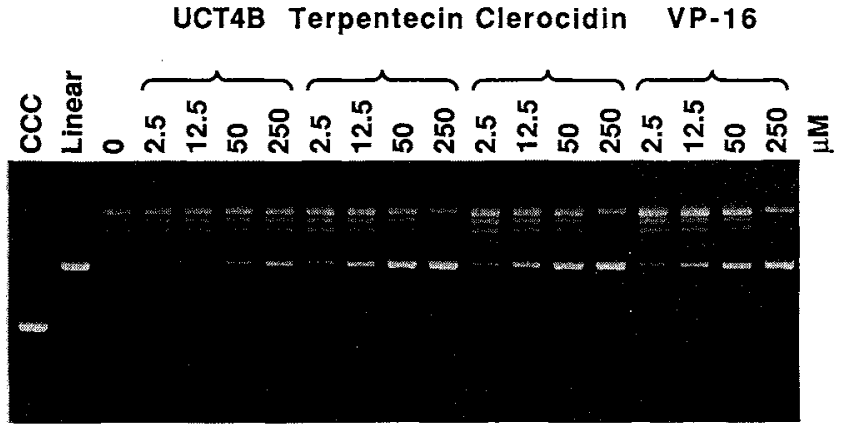

Topoisomerase II was purified from calf thymus as described previously ${ }^{4)}$. Stock solutions of drugs were dissolved in dimethyl sulfoxide at $50 \mathrm{mM}$, stored at $-20^{\circ} \mathrm{C}$ and diluted in methanol containing $40 \%$ dimethyl sulfoxide before use. Reactions $(20 \mu 1)$ containing $50 \mathrm{~mm}$ Tris- $\mathrm{HCl}(\mathrm{pH} 7.5), 100 \mathrm{mM} \mathrm{KCl,} 10 \mathrm{~mm}$ $\mathrm{MgCl}_{2}, 1 \mathrm{mM} \mathrm{ATP}, 0.5 \mathrm{~mm}$ dithiothreitol, $0.5 \mathrm{mM}$ EDTA, $30 \mu \mathrm{g} / \mathrm{ml}$ of bovine serum albumin, $0.4 \mu \mathrm{g}$ of pUL402 DNA, and DNA topoisomerase II with or without drug were incubated at $37^{\circ} \mathrm{C}$. After 30 minutes, reactions were terminated by the addition of $2 \mu \mathrm{l}$ of solution containing $5 \%$ SDS and $2.5 \mathrm{mg} / \mathrm{ml}$ of Proteinase K. Following an additional incubation at $37^{\circ} \mathrm{C}$ for 30 minutes, the sample were electrophoresed through a $1.2 \%$ agarose gel in $89 \mathrm{~mm}$ Tris-borate (pH 8.3), 2 mM EDTA buffer containing $0.1 \%$ SDS. The concentration of topoisomerase II used in the DNA cleavage assay was at least 20 times higher than that required for full relaxation of pUL402 DNA in the relaxation assay. After electrophoresis, gels were stained with ethidium bromide and photographed over UV illumination. Lane CCC, covalently closed circular (CCC)-DNA control; lane Linear, linear DNA control.

organic layer was concentrated and further purified by silica gel chromatography (Licroprep Si60) using $\mathrm{CHCl}_{3}-\mathrm{MeOH}(50: 1)$ as an eluent. The active fractions were combined, and further purified by HPLC packed with ODS (YMC Pack ODS SH-363-5) to yield $100 \mathrm{mg}$ of UCT4B.

UCT4B was obtained as a white powder and the physico-chemical properties are summarized in Table 1. UCT4B was readily soluble in $\mathrm{MeOH}$, acetone and DMSO and slightly soluble in $\mathrm{H}_{2} \mathrm{O}$ but hardly soluble in $n$-hexane. The molecular formula of UCT4B was determined as $\mathrm{C}_{20} \mathrm{H}_{28} \mathrm{O}_{7}$ by HREI-MS. The structure of UCT4B (Fig. 1) was assigned by ${ }^{1} \mathrm{H}$ and ${ }^{13} \mathrm{C}$ NMR spectroscopic studies, which showed that UCT4B is in an equilibrium state of tautomer similar to terpentecin and clerocidin ${ }^{5,6)}$. The structure determination and chemical properties of UCT4B will be reported in a separate paper ${ }^{7}$.

The topoisomerase II mediated DNA cleavage activity of UCT4B was studied in vitro using purified calf thymus topoisomerase II and plasmid DNA. Fig. 2 shows a photograph of agarose gel electrophoresis comparing the topoisomerase II mediated DNA cleavage activity of UCT4B with terpentecin, clerocidin and VP-16. At concentrations greater than $12.5 \mu \mathrm{M}$ of UCT4B, the linear full length DNA appeared as a result of DNA double strand cleavage. In the absence of topoisomerase II,
Table 2. Antimicrobial activity of UCT4B.

\begin{tabular}{lc}
\hline \multicolumn{1}{c}{ Microorganism } & MIC $(\mu \mathrm{g} / \mathrm{ml})$ \\
\hline Staphylococcus aureus ATCC 6538 & 4.1 \\
Enterococcus faecium ATCC 10541 & 4.1 \\
Bacillus subtilis No. 10707 & 8.3 \\
Klebsiella pneumoniae ATCC 10031 & 2.1 \\
Escherichia coli ATCC 26 & $>100$ \\
Pseudomonas aeruginosa BinH No. 1 & $>100$ \\
Proteus vulgaris ATCC 6897 & $>100$ \\
Salmonella typhi ATCC 9992 & $>100$ \\
Shigella sonnei ATCC 9290 & $>100$ \\
Candida albicans ATCC 10231 & $>100$ \\
\hline
\end{tabular}

UCT4B did not induce any changes on the supercoiled structure of pUL406 DNA (data not shown), and did not intercalate into DNA. UCT4B forms a cleavable complex that is stable to heat $\left(65^{\circ} \mathrm{C}\right)$ and salt $(0.5 \mathrm{M} \mathrm{NaCl})$ treatment, which is strictly different from known topoisomerase II poisons such as $m$-AMSA and VP-1 $6^{4}$.

UCT4B exhibits an antimicrobial activity against Gram-positive bacteria and Klebsiella pneumoniae (Table 2). UCT4B shows cytotoxic activity in vitro with $\mathrm{IC}_{50}$ values of $11.9 \mu \mathrm{g} / \mathrm{ml}$ against a human tumor cell line HeLa S3. UCT4B prolonged the life span of mice inoculated with leukemia P388 ip, showing an ILS $37 \%$ at an single ip dose of $25 \mathrm{mg} / \mathrm{kg}$. Further sutdies on antitumor spectra and 
toxicity of UCT4B are in progress.

\section{Acknowledgments}

The authors are grateful to Miss Mitsue AoYagi and Miss Mitsuko Matsumoto for technical assistance.

\section{References}

1) Wang, J. C.: DNA topoisomerases. Annu. Rev. Biochem. 54: 665 697, 1985

2) LiU, L. F.: DNA topoisomerase posions as antitumor drugs. Annu. Rev. Biochem. 58: 351 375, 1989

3) D'ARPA, P. \& L. F. LiU: Topoisomerase-targeting antitumor drugs. Biochim. Biophys. Acta 989 $163 \sim 177,1989$

4) KaWAda, S.; Y. Yamashita, N. FuJil \& H. NAKano:
Induction of heat-stable topoisomerase II-DNA cleavable complex by nonintercalative terpenoides, terpentecin and clerocidin. Can. Res. 51: 2922 2925, 1991

5) Tamamura, T.; T. Sawa, K. Isshiki, T. Masuda, Y. Homma, H. Iinuma, H. Naganawa, M. Hamada, T. TAKEUCHI \& H. UMEZAWA: Isolation and characterization of terpentecin, a new antitumor antibiotic. J. Antibiotics 38: $1664 \sim 1669,1985$

6) Andersen, N. R. \& P. R. Rasmussen: The constitution of clerocidin: a new antibiotic isolated from Oidiodendron truncatum. Tetrahedron Lett. 25: $465 \sim 468,1984$

7) Uosaki, Y; S. KaWada, H. Nakano, H. SaNo \& Y. SAITOH: Structure of UCT4B, a new antitumor antibiotic inducing topoisomerase-DNA cleavable complex. Tetrahedron Lett., to submitted 